\title{
Chemical Compositions and Antioxidant Potentials of the Aqueous-Methanol Extract and Essential Oil of Gongronema latifolium Leaves
}

\author{
Ogochukwu Rita NGWU, Sabinus Oscar 0 EZE* and Bennett Chima NWANGUMA \\ Department of Biochemistry, Nigeria
}

*Corresponding author: Sabinus Oscar O EZE, Department of Biochemistry, Enugu State, Nigeria

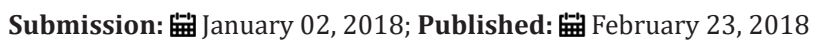

\begin{abstract}
Protection of cells against damage by reactive oxygen species is a way of preventing disease conditions and food-derived anti-oxidants, which can prevent such damages, are of great interest. Polyphenols and essential oil of medicinal plants are antioxidants and this turns our attention to Gongronema latifolium. Phytochemicals and essential oil of G. latifolium leaves were extracted and their mechanisms of antioxidant action were investigated. Aldehydes, octanal and decanal as well as monoterpene class of compounds were detected from the essential oil of G. latifolium. The essential oil and aqueous-methanol extracts showed strong antioxidant activities by inhibition of lipid peroxidation, chelation of Iron (II) ions, scavenging of both Hydroxyl and $\alpha, \alpha$-diphenyl- $\beta$-picryl-hydrazyl radicals. The study demonstrates the strong antioxidant potentials of the essential oil and aqueous-methanol extracts which explains the potency assigned to it in traditional medicine and highlights its potential usefulness in preventing lipid peroxidation in food systems.
\end{abstract}

Keywords: Antioxidant activities; Free Radicals; Phytochemicals; Food systems, traditional medicine

\section{Introduction}

Metabolism of alcohols, toxins and drugs generate reactive oxygen species (ROS) as byproducts in biological systems which could attack and damage major cellular components such as; lipids, carbohydrates and proteins. This could lead to various diseases such as cancer, diabetes, high blood pressure, etc. [1]. Any intervention (in form of antioxidants) that could scavenge these reactive oxygen species could prevent the toxicities or diseases arising from the activities of ROS. Literature has it that herbal medications have been used for relief of symptoms of diseases [2]. Edet [3] observed that polyphenols and essential oil of aromatic and medicinal plants are natural antioxidants. These essential oil and extracts have been used for many thousands of years in food preservation, alternative medicine and natural therapies. A number of herbs, spices, essential oil and other extracts have also been successfully tested for antimicrobial and antioxidant potentials $[4,5]$. The increasing preference for natural foods has encouraged the food industry to include natural antioxidants in various products to delay oxidative degradation of lipids, improve quality and nutritional value of foods, in preference to synthetic antioxidants which have some side effects [6-8]. Eze \& Nwanguma [9] have evaluated the application of G. latifolium in food preservation.

In addition natural antioxidants are multifunctional and can exert their antioxidant potentials by different mechanisms. Information abound in literature on the phytochemical and nutrient composition of G. latifolium [1], similarly, the anti-ulcer, analgesic, anti-pyretic and anti-microbial activities of the various extracts (in different solvents) of the different parts of the plant have been reported [10]. Gongronema latifolium, is a tropical rainforest plant found in countries such as: Nigeria, Cote d'Ivoire, Sierra Leone, Ghana, Senegal and some parts of Asia. It belongs to the family Asclepiadaceae, and is primarily used for medicinal and nutritional purposes [10]. Different extracts from the various parts of the plants are used for the treatment of diabetes, high blood presure, asthma, sickle cell anaemia, Bilharzia, viral hepatities, cough, intestinal worms, dysentry, dispepsia and malaria [11]. However, there is the need for further investigations of the antioxidant activities of the essential oil and various extracts of this widely used medicinal plant. This study was therefore undertaken to investigate the antioxidant potentials and the in-vitro mechanism of antioxidant activity of extracts of Gongronema latifolium leaves.

\section{Materials and Methods}

\section{Chemicals/Reagents}

Folin-Ciocalteu reagents were obtained from Merk Co. (Munbai, India). 2,2-diphenyl-1-pycrylhydrazyl (DPPH) was obtained from Sigma-Aldrich GmbH. Other chemicals used were from standard sources and were of analytical grade. Reagents were freshly prepared unless where otherwise stated.

\section{Extraction of aqueous-methanol extract}

Fresh leaves of Gongronema latifolium were collected from a local market and authenticated by the Curator of Department of Botany of the University of Nigeria, Nsukka. These were air dried 
at a temperature of $30{ }^{\circ} \mathrm{C}$ and milled using a laboratory milling machine (Thomas-Wiley, model 4). 500g of milled dry sample was soaked in $1200 \mathrm{~mL}$ of aqueous-methanol in the ratio $(4: 1$; methanol: water), and allowed to stand for $24 \mathrm{hr}$. The mixture was filtered using Whatmann No. 1 filter paper. The filtrate was concentrated using a temperature controlled MRC stainless steel water bath model WBO-200 at a constant temperature of $60^{\circ} \mathrm{C}$ for $72 \mathrm{hr}$.

\section{Extraction of the essential oil}

$860 \mathrm{~g}$ of milled sample of air dried G. latifolium leaves was soaked in $1500 \mathrm{~mL}$ of $\mathrm{n}$-Hexane for $72 \mathrm{hr}$. This was filtered using Whatmann No. 1 filter paper and the solvent recovered using soxhlet apparatus.

\section{Determination of total phenol contents of the extracts}

Total phenol content was measured using Folin-Ciocalteu's reagent as described by Safaeian et al. [12]. Total phenol was calculated using the equation below and expressed as mg/g Tannic Acid Equivalents (TAE).

$$
\text { Total phenol }=\frac{A \times M}{A_{0} \times M_{0}}
$$

Where $A=$ Absorbance of sample at $765 \mathrm{~nm}, M=$ mass of sample (mg), $A_{0}=$ Absorbance of tannic acid and $M_{0}=$ mass of tannic acid (g)

\section{Phytochemical analysis of aqueous-methanol extract}

The methods of Harborne (1998) and that of Trease and Evans (1983) were used for the identification of phytochemicals in the extracts

\section{GC/MS analysis of the essential oil}

Analysis was based on the method of Mothana et al. [13] with the following modifications: The essential oil was subjected to GCMS analysis using the instrument Trace GC ultra Thermo Scientific DSQII, equipped with TR-5ms fused silica capillary column of $30 \mathrm{~m}$ length, $0.25 \mathrm{~mm}$ diameter and $0.25 \mu \mathrm{M}$ film thicknesses. For GC-MS detection, an electron ionization system with ionization energy of $70 \mathrm{eV}$ was used. Helium gas (99.99\%) was used as a carrier gas at a constant flow rate of $1.5 \mathrm{~mL} / \mathrm{min}$. The sample injector temperature was maintained at $200{ }^{\circ} \mathrm{C}$. The oven temperature was initially maintained at $14^{\circ} \mathrm{C}$ for $1 \mathrm{~min}$ and then gradually increased to 300 ${ }^{\circ} \mathrm{C}$ for $5 \mathrm{~min}$.

The sample $(1 \mu \mathrm{L})$ was auto injected for analysis. The eluted component was detected in the mass detector. The spectrum of the unknown component was compared with the spectrum of the known component stored in the National Institute of Standards and Technology (NIST) library.

\section{Antioxidant Assays}

Quantitative (2, 2-diphenyl-1-picryl-hydrazyl) DPPH free radical scavenging assay: The scavenging activity on DPPH free radicals by the extract was carried out as described by Dehshahri et al. [14].

$$
\text { DPPH Scavenging effect }(\%)=\frac{A_{0}-A_{i}}{A_{0}} \times \frac{100}{1}
$$

Where $A_{0}$ is the absorbance of the control reaction and $A_{i}$ is the absorbance in the presence of the leaf extracts. The absorbance was read at $517 \mathrm{~nm}$.
Hydroxyl Radical ( $\mathbf{O H}-)$ scavenging assay: The determination of the scavenging effect of the extract on the hydroxyl radical (.OH-) was carried out according to the method of Pratap-Chandran et al. [15].

Lipid peroxidation assay: Lipid peroxidation assay was carried out as reported by Olorunnisola et al. [16].

\section{Determination of iron (II) chelation activity}

The ability of the Gongronema latifolium extracts to chelate ferrous ions was carried out as described by Nabavi et al. [17].

\section{Statistical Analysis}

The results were expressed as the mean \pm standard deviation, Data analysis was performed by one way analysis of variance followed by Tukey post-hoc test using SPSS software version 16.0. $\mathrm{p}<0.05$ was considered to be significant. The statistical analysis could be found in the additional file attached.

\section{Results}

\section{Extraction yield and phenol content of the aqueous- methanol extract}

Extraction with aqueous-methanol resulted in an extract yield of $39.63 \%$ of the dry weight of sample. Aqueous-methanol extract showed a high total phenol content of $329.24 \pm 22 \mathrm{mg}$ of tannic acid equivalent/g of extract (TAE/g).

\section{Phytochemical analysis of the Aqueous-methanol extract}

The phytochemical screening of the aqueous-methanol extract (Table 1) reflects the medicinal importance of the plant extract. Bioactive constituents such as tannins, flavonoids and reducing sugars were detected in moderate amounts, while other compounds such as steroids, saponins, alkaloids and soluble carbohydrates were detected in trace amounts.

Table 1: Phytochemical constituents of the Aqueous-methanol extract.

\begin{tabular}{|c|c|c|}
\hline Compounds & Qualitative & Quantitative (mg/100g) \\
\hline Phenol & ++ & $33.24 \mathrm{mg} / \mathrm{TAE} / \mathrm{g}$ \\
\hline Tannin & + & $5.74 \pm 0.02646$ \\
\hline Reducing sugar & ++ & $4.35 \pm 0.0208$ \\
\hline Soluble carbohydrate & + & $0.62 \pm 0.03055$ \\
\hline Steroid & + & $8.55 \pm 0.04583$ \\
\hline Saponin & + & $8.44 \pm 0.04583$ \\
\hline Flavonoid & ++ & $43.23 \pm 0.02646$ \\
\hline Alkaloid & + & $27.67 \pm 0.04933$ \\
\hline
\end{tabular}

++++ Highly present $++=$ moderately present $+=$ slightly present

\section{Composition of the essential oil and antioxidant capacities of the extracts}

The chromatogram of the essential oil as determined by Gas chromatography/Mass spectrometry techniques shows its constituents and relative proportion (Area \%) as listed on Table 2. The base peaks of the chromatogram shows a complex mixture of compounds such as limonene (32.92\% total) and $\alpha$-pinene $(7.89 \%$ total) whose peaks occurred twice. Other constituents are: octanal (40.88\%), sabinene (8.52\%), cineole (8.29\%), and decanal (1.52\%). 
Table 2: Compounds detected from GC/MS analysis of the n-Hexane leaf extract (Essential oil).of G. latifolium.

\begin{tabular}{|c|c|c|c|c|c|c|}
\hline Apex & Compounds & Chemical Name & $\begin{array}{c}\text { Retention Time } \\
\text { (min) }\end{array}$ & Peak Area (\%) & $\begin{array}{c}\text { Chemical } \\
\text { Formulae }\end{array}$ & $\begin{array}{c}\text { Molecular } \\
\text { Weight (g/mol) }\end{array}$ \\
\hline 7.04 & Octanal & Octanal & 0.8 & 40.88 & $\mathrm{C}_{8} \mathrm{H}_{16} \mathrm{O}$ & 128.21 \\
\hline 8.32 & Limonene & 1-Methyl-4-prop-1-en-2-ylcyclohexene. & 1.18 & 29.15 & $\mathrm{C}_{10} \mathrm{H}_{16}$ & 136.23 \\
\hline 6.3 & Sabinene & $\begin{array}{c}\text { 4-Methylene-1-(1-methylethyl) bicyclo [3.1.0] } \\
\text { hexane. }\end{array}$ & 0.29 & 8.52 & $\mathrm{C}_{10} \mathrm{H}_{16}$ & 136.23 \\
\hline 6.59 & Cineole & 1,3,3-Trimethyl-2-oxabicyclo [2,2,2] octane. & 0.28 & 8.29 & $\mathrm{C} 10 \mathrm{H} 180$ & 154.25 \\
\hline 4.41 & $\alpha$-Pinene & $\begin{array}{c}\text { (1S,5S)-2, 6,6-Trimethylbicyclo [3.1.1] hept-2- } \\
\text { ene. }\end{array}$ & 1.16 & 6.04 & $\mathrm{C}_{10} \mathrm{H}_{16}$ & 136.23 \\
\hline 10.79 & Limonene & 1-Methyl-4-prop-1-en-2-ylcyclohexene. & 0.55 & 3.77 & $\mathrm{C}_{10} \mathrm{H}_{16}$ & 136.23 \\
\hline 5.88 & $\alpha$-Pinene & $\begin{array}{c}\text { (1S,5S)-2, 6,6-Trimethylbicyclo [3.1.1]hept-2- } \\
\text { ene. }\end{array}$ & 0.39 & 1.85 & $\mathrm{C}_{10} \mathrm{H}_{16}$ & 136.23 \\
\hline 14.25 & Decanal & Decanal & 0.87 & 1.52 & $\mathrm{C}_{10} \mathrm{H}_{20} \mathrm{O}$ & 156.27 \\
\hline
\end{tabular}

Four different methods were used to investigate the antioxidant property and potential of the plant extract and its essential oil, and the results show a concentration-dependent antioxidant activity of both extract and the oil.

There was an increase in the percentage scavenging activity of hydroxyl radical with increasing concentrations of the extracts as well as the standard drugs. The highest $\mathrm{OH}^{-}$radical scavenging activities $(70.54 \pm 0.14 \%$ and $60.84 \pm 0.06 \%)$ were recorded for essential oil, aqueous-methanol extract and the standard drug respectively at a concentration of $4.0 \mu \mathrm{g} / \mathrm{ml}$ (Figure 1 ).

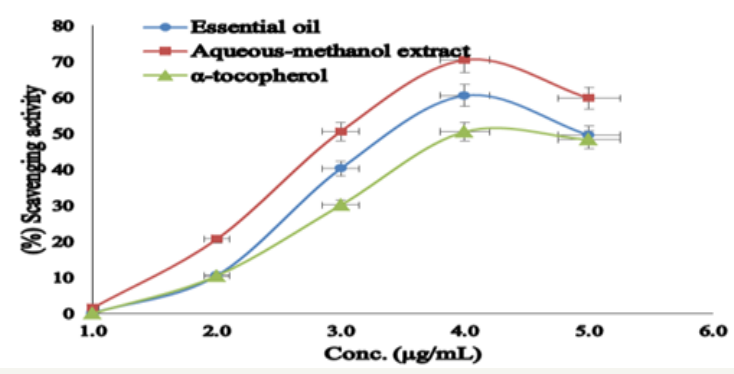

Figure 1: Hydroxyl radical scavenging activity of both the essential oil and aqueous-methanol leaf extracts of $G$. latifolium.

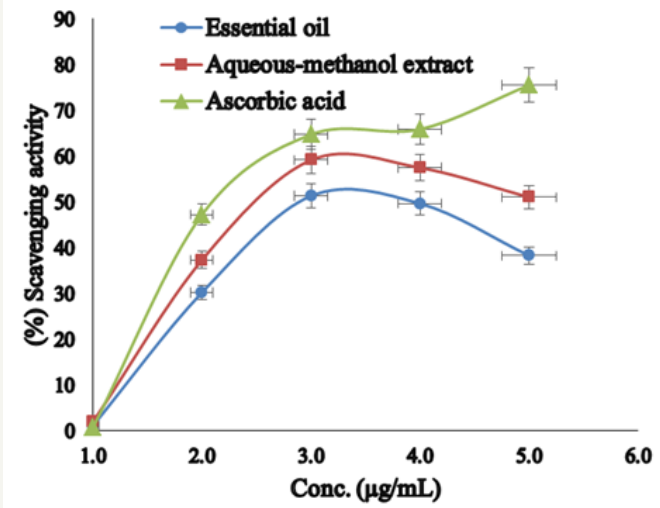

Figure 2: DPPH radical scavenging activity of both the essential oil and aqueous-methanol leaf extracts of $G$. latifolium.
The highest values of DPPH radical scavenging activity of $59.42 \pm 1.72 \%$ and $48.54 \pm 2.25 \%$ were obtained at a concentration of $3.0 \mathrm{mg} / \mathrm{mL}$ for the essential oil and aqueous-methanol extract respectively, while $74.54 \pm 1.90 \%$ was observed for ascorbic acid (drug standard) at a concentration of $5.0 \mathrm{mg} / \mathrm{mL}$ (Figure 2). The DPPH activities of the aqueous methanol extracts and the essential oil were both significantly lower $(p<0.05)$ that of ascorbic acid.

The inhibition of $\mathrm{Fe}^{2+}$-induced lipid peroxidation was assayed by the TBARS formation assay. The extracts showed a dose-dependent inhibition of lipid peroxidation (Figure 3). The maximum \% inhibition of $\mathrm{Fe}^{2+}$ induced lipid peroxidation were $39.77 \pm 0.14$ $\%, 30.71 \pm 0.28 \%$, and $19.71 \pm 0.09 \%$ for essential oil, aqueousmethanol extract and $\alpha$-tocopherol respectively at a concentration of $2.35 \mathrm{mg} / \mathrm{mL}$ each.

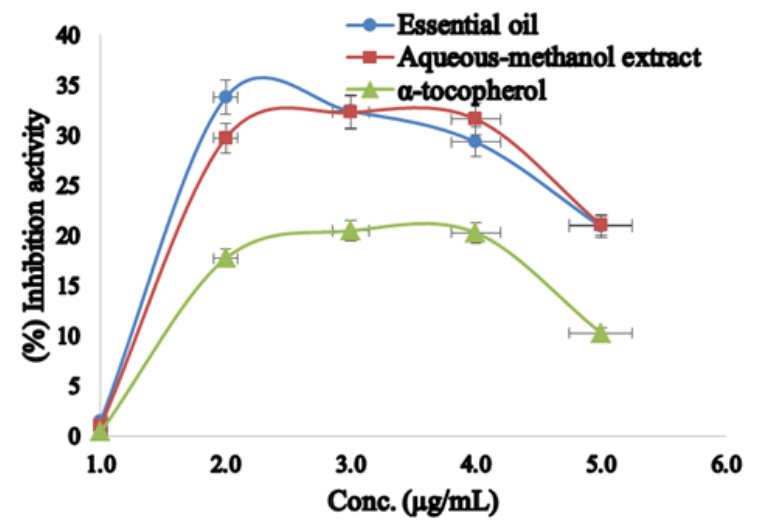

Figure 3: Lipid peroxidation inhibition activities of both the essential oil and aqueous-methanol leaf extracts of $G$. latifolium.

It was also observed that at this concentration, the extract and essential oil performed better than the standard drug. Lipid peroxidation of the aqueous-methanol extracts shows nonsignificant increase $(p>0.05)$ when activities of essential oil was compared with the activities of aqueous methanol extract. The EO and aqueous-methanol extract exhibited a significantly $(\mathrm{p}<0.5)$ higher antioxidant activity than $\alpha$-tocopherol (Figure 3). For the aqueous-methanol extract and the standard drug, the highest metal 
chelating activities of $53.30 \pm 0.48 \%$, and $49.77 \pm 3.47$ respectively were obtained at a concentration of $3 \mathrm{mg} / \mathrm{mL}$ comparatively; a chelating activity of $39.72 \pm 1.55 \%$ was obtained at the concentration of $3.0 \mu \mathrm{g} / \mathrm{mL}$, with the essential oil (Figure 4). There were no significant $(p>0.05)$ difference between the percentage chelating activity of the aqueous-methanol extract and that of the standard drug though activity from both were significantly $(\mathrm{p}<0.05)$ more than the essential oil.

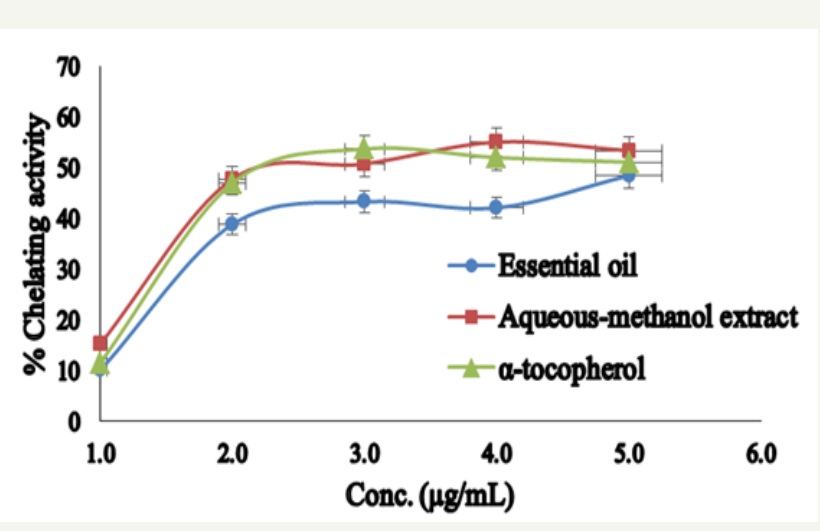

Figure 4: Iron (ii) chelation activity of both the essential oil and aqueous-methanol leaf extracts of G. latifolium.

\section{Discussion}

The increase in the search for natural alternatives for synthetic food preservatives and antioxidants has necessitated an increase in the evaluation of several plants as potential sources of bioactive compounds. The results of this investigation showed that there are high concentrations $(\mathrm{mg} / 100 \mathrm{~g})$ of phytochemicals such as flavonoids $(43.23 \pm 0.026)$, alkaloids $(27.67 \pm 0.049)$ and phenols $(33.24 \mathrm{mg} / \mathrm{TAE} / \mathrm{g})$, moderate concentrations of saponins $(8.44 \pm 0.046)$, steroids $(8.55 \pm 0.046)$, tannins $(5.73 \pm 0.026)$ and reducing sugars $(4.35 \pm 0.02)$ while there is slight presence of soluble carbohydrates. This result is in agreement with Enemor et al. [18] who observed substantial presence of alkaloids, flavonoids and saponins from G. latifolium leaves. Offor \& Uchenwoke [19] also observed higher levels of saponins, tannins, flavonoids and tannins than obtained in this work. Similar observations were made by Osuagwu et al. [20]. The presence of phytochemicals confers nutritional, industrial, therapeutic, as well as economic potential on Gongronema latifolium [20]. This investigation reported a phenol content of $329.24 \pm 22 \mathrm{mg} / \mathrm{TAE}$ in aqueousmethanol extract. Comparatively high levels of phenols have been reported in leaf extracts of other plants, especially those with preventive potentials against oxidative damage [21,22]. Phenols are antimicrobial agents with disease prevention capabilities and also with positive correlations with antioxidant activities. Moderate amounts of flavonoids, tannins and saponins were also detected in the leaf extracts of G. latifolium plant as reported elsewhere [23]. The presence of these compounds could be responsible for the biological activities of leaf extracts of the plant and could justify its use in the treatment of a variety of conditions including diabetes mellitus, gastrointestinal diseases and malaria [24].

The essential oil recorded in this investigation are: Octanal, two isoforms of Limonene, sabinene, cineole, decanal and two isoforms of pinene: $\alpha$ - and $\beta$-pinene. The simple components of this plants essential oil as recorded are in agreement with the observation of Zuzarte and Salguero (2015) that some plants essential oil were composed of constituents as simple as 5,7 or 8 compounds while others consists of up to 37 or more complex compounds. The content of oil and its chemical composition determine the aroma of the raw materials and this composition depends on the place of origin, plant growth stage, oil distillation methods, and according to the different parts of the plants (Chamorro et al. 2008; Zawislak, 2013).

The observation of two peaks for limonene and pinene on the chromatogram could be as a result of optical isomerism as these compounds are known to exist as enantiomers. The presence of other constituents such as octanal, sabinene, cineole, and decanal as found in this study, is in agreement with literature as Liang \& Kitts [25] had observed that essential oil consist of a mixture of esters, aldehydes, ketones, terpenes and phenolic compounds, which are responsible for the characteristic flavour and aroma of the particular spice or herb. Sabinene contributes to the spiciness of plants and are good additives to perfumes. Pinenes are interesting compounds for perfumery and used in the synthesis of compounds like; terpineol, borneol, and camphor (Zuzarte and Salgueiro, 2015) Limonene has attractive odour and are good additives in cosmetics and foods. The essential oil correlate with natural antioxidants with possible food applications.

Several in vitro techniques have been applied to determine the antioxidant activities of different extracts from plants. It is known that antioxidants which are known to neutralize the action of reactive oxygen species thereby protecting the cells from various damages, exert their antioxidant actions through several mechanisms such as inhibition of lipid peroxidation, chelation of Iron (II) ions, scavenging of both Hydroxyl (.OH') and $\alpha, \alpha$-diphenyl- $\beta$-picryl-hydrazyl (DPPH) radicals among others. In this investigation, the capability of the plant essential oil as well as its aqueous-methanol extracts to donate electrons was measured using the DPPH purple coloured solution which was made colourless by the action of the plant extracts. A large decrease in the absorbance of the reaction mixture indicates significant free radical scavenging activity of the compound under test [26]. In this study, there is a concentration-dependent increase in antioxidant activity of both extract and the oil on the DPPH decolourization. The DPPH activities of the aqueous methanol extracts and the essential oil were both significantly lower $(\mathrm{p}<0.05)$ than that of ascorbic acid at all the concentrations tested but it shows that the extracts have phytochemical contents that have the capacity to donate hydrogen to reactive oxygen species thereby rendering them harmless to the cells.

Hydroxyl radical reacts with polyunsaturated fatty acids of the cell membranes and causes damages to the cell. This radical is generated by the reaction of $\mathrm{H}_{2} \mathrm{O}_{2}$ which occurs naturally in the air, water, human body, plants, micro-organisms and foods [26]. $\mathrm{H}_{2} \mathrm{O}_{2}$ is rapidly decomposed into oxygen and leads to hydroxyl radical 
$(. \mathrm{OH})$ production which initiates lipid peroxidation and causes DNA damage among other cellular components. It is interesting to observe that in all the concentrations tested, the test samples showed more hydroxyl radical scavenging activity than the standard $\alpha$-tocopherol drug used. However, difference in hydroxyl scavenging activity was found to be significantly higher $(p<0.05)$ than that of $\alpha$-tocopherol at all the concentrations tested. This suggests that the extracts have phytochemical constituents with great antioxidant potentials. The variations in the scavenging activity on hydroxyl radical with increasing concentrations of the extracts with maximum activity at $4 \mu \mathrm{g} / \mathrm{mL}$ as well as the standard drugs is in agreement with the observations of Tyagri et al. [4] who obtained maximum hydroxyl radical scavenging activity with a concentration of $1 \mathrm{mg} / \mathrm{mL}$ of the extract. It would appear that a purer extract was used in this investigation. It is known that some antioxidants tend to exhibit pro-oxidant effects at higher concentrations.

The essential oil and aqueous-methanol extract were also effective as iron chelators, demonstrating chelation potentials that were comparable to that of the standard, $\alpha$-tocopherol (Figure 4). From the foregoing, it could be deduced that essential oil and the extracts exhibited antioxidant activities by all four antioxidant mechanisms employed in this study. The most significant $(\mathrm{P}<0.05)$ of the four mechanisms, are the lipid peroxidation: - (for both the aqueous-methanol and essential oil) and by iron (II) chelation activity (for the aqueous-methanol extract only). The aqueousmethanol extract and essential oil exhibited significantly $(p>0.05)$ greater antioxidant activity through inhibition of lipid peroxidation than the standard drug used. The iron (II) cheating potential of the aqueous-methanol extract is deserving of further significance because several natural antioxidants, especially polyphenols, possess potential metal-binding sites in their structure. Part of their antioxidant function may therefore be elicited through metal chelation [27-29]. Metal chelation and radical chain breaking by primary radical interception and alkoxyl breaking reactions are presently regarded as the most important antioxidant mechanisms of natural antioxidants in food systems [29]. Therefore, Gongronema latifolium extracts, may serve as a good metal chelating agent, as well as inhibitors of lipid peroxidation. Eze \& Nwanguma [9] had earlier reported the inhibitory activity of tannins extract of Gongronema latifolium on lipoxygenase, a deteriorative enzyme in lipid-based foods. Lipoxygenase molecules contain one atom of iron. The iron atom is in the high spin Fe (II) state in the native resting form of lipoxygenase and it must be oxidized to Fe (III) by the reaction product, fatty acid hydroperoxides or hydrogen peroxide, before it becomes active as an oxidation catalyst [28] Thus, it could be inferred that the inhibition of lipoxygenase as reported by Eze \& Nwanguma [9], could possibly be through the chelation of iron (II) ion in this enzyme, thereby making the iron in the prosthetic group unavailable for the enzyme's activity. Lipid peroxidation could be hindered through the sequestration of the metal catalysts. The metal-chelation activity of G. latifolium extracts was supported by the work of Nwanjo et al. [30], which reported the In vivo anti-lipid peroxidation properties of Gongronema latifolium leaf extract. Metal chelators may not just serve as antioxidants, but may also serve as antimicrobial by sequestering free iron required for microbial growth [31].

Plant extracts are increasingly being used in foods as preservatives, thus the antioxidant activity of extracts from this plant, posits that it could gain application in food processing/ preservation especially in meat processing, where ionic iron released from heme pigments and ferritin may be considered as the major catalyst for lipid peroxidation, as well as in biological system to ameliorate oxidative stress.

The results from the in-vitro antioxidant tests performed in this study demonstrate that EO and aqueous-methanol extracts of $G$. latifolium leaves suggest that the medicinal potential of the plant could be due partly to its content of compounds with potent antioxidant properties. These antioxidant potentials, especially the iron (II) chelating property could also be exploited in the inhibition of oxygen-mediated lipid peroxidation in food systems.

\section{References}

1. Chime SA, Onyishi JV, Ugwuoke PU, Attama AA (2010) Evaluation of the properties of Gongronema latifolium in phospholipon $90 \mathrm{H}$ based solid lipid microparticles (SLMs): an antidiabetic study. J Diet Suppl 11(1): 7-18.

2. Maqsood SP, Samoon MH, Balange AK (2010) Effect of dietary chitosan on non-specific immune response and growth of Cyprinus carpio challenged with Aeromonas hydrophilia. Int Aquo Res 2(2): 77-85.

3. Edet EE (2013) Intragastric administration of Gongronema latifolium crude leaf extract lowers fasting blood glucose in diabetic rats. J Pharm Biomed Sci 33(33): 1495-1501.

4. Tyagri SN, Singh RA, Saxena RA, Patel BD (2010) In vitro antioxidant activity of methanolic and aqueous extract of Flacourtia indica Merr. American-Eurasian J Sci Res 5(3): 201-206.

5. Velasco V, Williams $P$ (2011) Improving meat quality through natural antioxidants. Chilean J Agric Res 71: 313-332.

6. Fereidoon S, Ying ZH (2010) Novel antioxidants in food quantity preservation and health promotion. Eur J lipid Sci Technol.

7. Lobo V, Patil A, Phatak A, Chandra N (2010) Free radicals, antioxidants and functional food: impact on human health. Pharmcogn Rev 4(8): 118126.

8. Nalgonda S (2012) Differences between the nutritional aspects of artificially and naturally ripened banana. J Food Proc Technol 3(10): 153.

9. Eze SOO, Nwanguma BC (2013) Effects of tannin extract of Gongronema latifolium on lipoxygenase from Cucumeropsis manii seeds. J Chem 2013(2013): Article ID 864095.

10. Akuodor GC, Idris-Usman MS, Mba CC, Megwas UA, Akpan JL, et al. (2010) Studies on anti-ulcer, analgesic, and anti-pyretic properties of ethanolic leaf extract of Gongronema latifolium in rodents. Afr J Biotechnol 9(15): 2316-2321.

11. Owu DU, Nwokocha CR, Obembe AO, Essien AD, Ikpi DE, et al. (2012) Effects of Gongronema latifolium ethanol leaf extract on gastric acid secretion and cytoprotection in stretozotocin Induced diabetic rats. West Ind Med J 61(9): 853-860.

12. Safaeian L, Gholamreza A, Shagavegh HJ, Aman H (2015) The effect hydro alcoholic extracts leaves of Moringa peregrina (Forssk) fiori on blood pressure and oxidative status in dexamethasone-Induced hypertensive rats. Adv Biomed Res 4: 101.

13. Mothana RA, Al-Said MS, Al-Yahya MA, Al-Rehaily AJ, Khaled JM (2013) GC and GC/MS analysis of essential oil composition of the endemic 
Soqotraen leucas virgata Balf and its antimicrobial and antioxidant activities. Int J Mol Sci 14(11): 23129-23139.

14. Dehshahri S, Wink M, Afshampuor S, Asghari G, Mohagheghzadeh A (2012) Antioxidant activity of methanolic leaf extract of Moringa peregrine (Forssk.). Fiori Res Pharm.Sci 7(2): 111-118.

15. Pratap-Chandran R, Vysakhi MV, Kannan M, Abdulkader S, SreekumaranNair A (2013) In vitro free radical scavenging activity of aqueous and methanolic leaf extracts of Aegle tamilnadensis abdul kader (Rutaceae). Int J Pharm Pharm Sci 5(3): 819-823.

16. Olorunnisola OS, Bradley G, Afolyan AJ (2012) Protective effect of T. violacea Rhizome extract against hypercholesterolemia-induced oxidative stress in Wister Rats. Molecules 17(5): 6033-6045.

17. Nabavi SF, Mohammad AE, Seyed M, Bahman E (2010) Antioxidant activity of flowers, stem and leaf extracts of Ferula gummosa Boiss. Grasas Aceites 61(3): 110809.

18. Enemor VHA, Nnaemeka OJ, Okonkwo OJ (2014) Minerals, vitamins, and phytochemical profile of $G$. latifolium: indices for assessment of its free radical scavenging, nutritional and anti-nutritional qualities. Int Res J Biol Sci 3(1): 17-21.

19. Offor CE, Uchenweze IO (2015) Phytochemical analysis and proximate composition of the leaves of G. latifolium. Global J Pharmacol 9(2): 159162.

20. Osuagwu AN, Ekpo IA, Okpako EC, Out P, Ottoho E (2013) The Biology utilization and phytochemical composition of the fruits and leaves of $G$. latifolium Benth. Agrotechnol 2: 16-115.

21. Amin MN, Dewan SMR, Noor W, Shahid-Ud-Daula V (2013) Characterization of chemical groups and determination of total phenolic content and In vitro antioxidant activities of ethanol extract of Ocimum sanctum leaves growing in Bangladesh. Eur J Expt Biol 3: 449-454.

22. Bursal E, Koksal E, Gulcin I, Bilsel G and Goren AC (2013) Antioxidant activity and polyphenol content of Cherry stem determined by LC/MS/ MS. Food Res. Int. 51(1): 66-74.

23. Imo C, Uhegbu FO (2015) Phytochemicals analysis of Gongronema latifolium Benth leaf using gas chromatographic flame ionization detector. Int J Chem Biomol Sci 1(2): 60-68. Gongronema latifolium extracts on rats. J Nat Sci Res 3(5): 37-44.
24. Udoh FV, Eshet GA, Akan JO, Edu FE (2013) Hypoglycemic effect of

25. Liang N, Kitts D (2014) Antioxidant properties of coffee components: assessment of methods that define mechanisms of action. Molecules 19(11): 19180-19208.

26. Gyamfi MA, Yonamine M, Aniya Y (1999) Free radical scavenging action of medicinal herbs from Ghana: Thonningia sanguine on experimentallyinduced liver injuries. General Pharmacol 32(6): 661-667.

27. Singh R, Neetu G, Anurag MA, Rajiv G (2012) Heavy metals and living systems. Indian J Pharmacol 43(3): 246-253.

28. Thiago CG, Angelo QM, Daniel R, Antonio A, Marcelo H (2015) Antioxidant activity of caffeic acid against Iron-Induced free radical generation- A chemical Approach. PLOS one 10(16): 1-12.

29. Sudan R, Madhulika B, Sahil G, Jasvinder S, Anupurna K (2014) Iron (Fell) chelation, Ferric Reducing antioxidating power, and immune modulating potential of Arisaema Jacquemontii (Himalayan Cobra LiLy). BioMed Res Int.

30. Nwanjo HU, Okafor MC, Oze G (2006) Anti-lipid peroxidative activity of Gongronema latifolium in streptozotocin-induced diabetic rats. Nig J Physiol Sci 21(1-2): 61-65.

31. Santos AL, Sodre CL, Valle RS, Silva BA, Abi-Chacra EA, et al. (2012) Antimicrobial action of chelating agents: Repercussions on the microorganism development, virulence and pathogenesis. Curr Med Chem 19(17): 2715-2737.

32. Ester RC, Griselda B, Alfredo FS, Grustavo A, Maria FZ (2008) Chemical composition of essential oil from Tagetes minuta L.leaves and flowers. J Argentin Chem Soc 96(1-2): 80-86.

33. Grazyna Z (2013) The chemical composition of essential Hyssop oil depending on plant growth stage. Acta Sci Pol Hortorum Cultus 12(3): 161-170.

34. Harborne J (1998) Phytochemical Methods: A Guide to Modern Technology of Plant Analysis. Chapman and Hall, New York, USA.

35. Monica Z, Ligia S (2015) Essential oil chemistry in bioactive essential oil and cancer. de Sausa (Ed.), Springer International Publishing, Switzerland.

36. Trease GE, Evans M (1983) Textbook of Pharmacognosy. (13 $3^{\text {th }}$ edn), Tindall, ELBS/ Bailiere, London, UK.

\section{Your subsequent submission with Crimson Publishers will attain the below benefits}

Creative Commons Attribution 4.0

International License

For possible submission use the below is the URL

Submit Article
- High-level peer review and editorial services

- Freely accessible online immediately upon publication

- Authors retain the copyright to their work

- Licensing it under a Creative Commons license

- Visibility through different online platforms

- Global attainment for your research

- Article availability in different formats (Pdf, E-pub, Full Text)

- Endless customer service

- Reasonable Membership services

- Reprints availability upon request

- One step article tracking system 